\title{
Impaired Water Handling in Chronic Obstructive Airways Disease
}

\author{
R. J. WHITE, D. F. WOODINGS
}

British Medical fournal, 1971, 2, 561-563

\section{Summary}

The response to a standard water load $(20 \mathrm{ml} / \mathrm{kg}$ body weight) was studied in 20 patients with chronic obstructive airways disease and in 13 healthy subjects. The percentage of the water load excreted in four hours was significantly lower in the patients (mean $51 \%$ ) than in the controls (mean $106 \%$ ). The maximum urine flow, osmolar clearance, free water clearance, and creatinine clearance were also significantly reduced in the patients. There was a significant inverse correlation between the percentage of load passed and the arterial $\mathrm{PCO}_{2}(\mathbf{r}=-0.798)$. Among the several possible causes of the reduced excretion of water which are discussed is a direct effect of hypercapnia.

\section{Introduction}

The association of oedema with chronic pulmonary disease is well known. In some patients this is related to pulmonary hypertension and failure of the right ventricle. However, most patients with obstructive airways disease who become oedematous have a normal cardiac output (Wade and Bishop, 1962) and the cause of oedema remains unexplained. In some other diseases associated with oedema, such as congestive heart failure and cirrhosis of the liver, there is incomplete urinary excretion of a water load (Levy et al., 1946; White et al., 1953), and this has been attributed to enhanced proximal tubular reabsorption of the glomerular filtrate (Bell et al., 1964; Gibson et al., 1970). We are unaware of similar studies in patients with chronic pulmonary dysfunction.

The response to a standard water load has been studied in patients with chronic pulmonary disease with and without a history of oedema, and the results have been related to glomerular filtration rate, pulmonary ventilation, and blood gas determinations.

\section{Methods}

Twenty patients aged 51 to 75 (mean 67) years with chronic obstructive airways disease were studied. Eight had at some time been oedematous and had received diuretics, but none had diuretics for two days before the water load was given. All were free of oedema at the time of the study. Thirteen healthy men aged 39 to 60 (mean 49) years volunteered as controls.

All subjects fasted from 12 midnight and at about 6 a.m. emptied their bladders and noted the time. At 9 a.m. they again passed urine and this was collected. An oral water load of $20 \mathrm{ml} / \mathrm{kg}$ body weight was then drunk over a period of 5 to 10 minutes. Thereafter urine was collected at hourly intervals for four hours. All subjects remained at rest in bed and did not smoke during the test. Oxygen was not given for the period of the investigation. Venous blood samples for urea, electrolytes, creatinine, and osmolarity determinations were taken just before the load was given. Tests of pulmonary ventilation

\footnotetext{
St. Bartholomew's Hospital, London EC1A 7BE

R. J. WHITE, M.D., M.R.C.P., Senior Medical Registrar (Present address: Whipps Cross Hospital, Leytonstone, London E.11)

D. F. WOODINGS, M.B., M.R.C.P., Registrar, Pathology Department
}

(Wright peak flow) and arterial blood gas measurements were made on the bronchitic patients on the same day.

The volume of the five urine specimens and their sodium, creatinine, and osmolarity were measured. Osmolar clearance

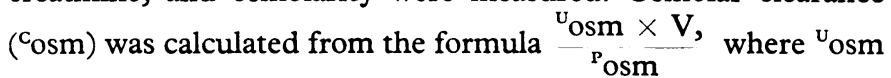
$=$ urine osmolarity $(\mathrm{mOsm} / \mathrm{kg}), \mathrm{V}=$ urine flow $(\mathrm{ml} / \mathrm{min})$, and ${ }^{\mathrm{P}} \mathrm{osm}=$ plasma osmolarity $(\mathrm{mOsm} / \mathrm{kg})$. Free water clearance $\left({ }^{C} \mathrm{H}_{2} \mathrm{O}\right)$ was calculated as $\mathrm{V}-{ }^{\mathrm{C}} \mathrm{Osm}$. The values for osmolar and free water clearance presented were from the hourly specimen with the largest volume, this being the time when the maximum diuresis was established. The rate of sodium excretion was also calculated for the hourly specimen with the largest urine volume. Creatinine clearance was calculated from the formula $\frac{U \times V \text {, where } U}{P}=$ urinary creatinine $(\mathrm{mg} / 100 \mathrm{ml})$, $\mathrm{V}=$ urine flow $(\mathrm{ml} / \mathrm{min})$, and $\mathrm{P}=$ plasma creatinine $(\mathrm{mg} / 100$ $\mathrm{ml}$ ). The value tabulated was the mean of that calculated from the five samples, and has been used as an index of glomerular filtration rate. Serum and urine electrolytes were determined by flame photometry. Serum and urine creatinine measurements were made by autoanalyser, based on the Jaffé reaction. Osmolarity of serum and urine was determined by the depression of freezing point with the Advance osmometer. Arterial oxygen tension $\left(\mathrm{PO}_{2}\right)$ was determined polarographically and carbon dioxide tension $\left(\mathrm{PCO}_{2}\right)$ by a Severinghaus electrode.

\section{Results}

Results obtained in the control subjects are summarized in Table I. They excreted $106 \pm 27 \cdot 7 \%$ of the volume given in the first four hours and achieved a maximum urine flow of $11.9 \pm 2.59 \mathrm{ml} / \mathrm{min}$. Their mean osmolar clearance was $4.5 \pm$ $1.01 \mathrm{ml} / \mathrm{min}$, giving a mean free water clearance of $7.4 \pm 2.36$ $\mathrm{ml} / \mathrm{min}$. The creatinine clearance was $117 \pm 22.1 \mathrm{ml} / \mathrm{min}$ and the sodium excretion rate was $237 \pm 83.5 \mu \mathrm{Eq} / \mathrm{min}$. The mean serum sodium was $140 \pm 2.5 \mathrm{mEq} / 1$.

TABLE I-Results in Control Subjects

\begin{tabular}{|c|c|c|c|c|c|c|c|}
\hline $\begin{array}{l}\text { Subject } \\
\text { No. }\end{array}$ & Age & $\begin{array}{c}\text { Percentage* } \\
\text { Load }\end{array}$ & $\mathrm{v}$ & $\begin{array}{r}\mathrm{H}_{2} \mathrm{O} \\
(\mathrm{ml}\end{array}$ & $\begin{array}{l}\text { osm } \\
\text { in) }\end{array}$ & $\mathrm{Na}$ & G.F.R. \\
\hline $\begin{array}{r}1 \\
2 \\
3 \\
4 \\
5 \\
6 \\
7 \\
8 \\
9 \\
10 \\
11 \\
12 \\
13\end{array}$ & $\begin{array}{l}52 \\
39 \\
57 \\
47 \\
43 \\
42 \\
49 \\
60 \\
42 \\
45 \\
51 \\
60 \\
43\end{array}$ & $\begin{array}{r}59 \\
105 \\
112 \\
129 \\
113 \\
137 \\
156 \\
80 \\
80 \\
131 \\
80 \\
100 \\
90\end{array}$ & $\begin{array}{r}8.0 \\
13.6 \\
8.9 \\
11.5 \\
13.3 \\
12.0 \\
16.1 \\
9.5 \\
11.8 \\
16.0 \\
10.7 \\
9.5 \\
14.0\end{array}$ & $\begin{array}{r}4 \cdot 9 \\
10 \cdot 0 \\
5 \cdot 2 \\
5 \cdot 5 \\
9 \cdot 6 \\
6 \cdot 1 \\
10 \cdot 6 \\
4 \cdot 2 \\
7 \cdot 7 \\
11 \cdot 0 \\
6 \cdot 3 \\
6 \cdot 4 \\
9 \cdot 3\end{array}$ & $\begin{array}{l}3 \cdot 1 \\
3 \cdot 6 \\
3 \cdot 7 \\
6 \cdot 0 \\
3 \cdot 7 \\
5 \cdot 9 \\
5 \cdot 5 \\
5 \cdot 3 \\
4 \cdot 1 \\
5 \cdot 0 \\
4 \cdot 4 \\
3 \cdot 1 \\
4 \cdot 7\end{array}$ & $\begin{array}{l}160 \\
136 \\
178 \\
284 \\
199 \\
330 \\
322 \\
332 \\
296 \\
320 \\
267 \\
123 \\
131\end{array}$ & $\begin{array}{r}65 \\
126 \\
117 \\
120 \\
115 \\
106 \\
117 \\
109 \\
104 \\
140 \\
108 \\
154 \\
144\end{array}$ \\
\hline $\begin{array}{l}\text { Mean } \\
\pm \text { S.D. }\end{array}$ & & $\begin{array}{l}106 \\
27 \cdot 7\end{array}$ & $\begin{array}{c}11.9 \\
2.59\end{array}$ & $\begin{array}{l}7 \cdot 4 \\
2 \cdot 36\end{array}$ & $\begin{array}{l}4 \cdot 5 \\
1 \cdot 01\end{array}$ & $\begin{array}{l}2.37 \\
83.5\end{array}$ & $\begin{array}{l}117 \\
22 \cdot 1\end{array}$ \\
\hline
\end{tabular}

* Percentage of water load excreted in four hours.

$\mathrm{V}=$ Maximum urine flow $(\mathrm{ml} / \mathrm{min})$.

$\mathrm{Na}=$ Rate of urinary sodium excretion $(\mu \mathrm{Eq} / \mathrm{min})$.

G.F.R. = Glomerular filtration rate $(\mathrm{ml} / \mathrm{min})$.

Results obtained in the patients are shown in Table II. They excreted only $51 \pm 27 \cdot 1 \%$ of a water load in four hours, with a maximum urine flow of $3.7 \pm 2.11 \mathrm{ml} / \mathrm{min}$. The mean osmolar clearance was also reduced (mean $2.0 \pm 0.83 \mathrm{ml} / \mathrm{min}$ ), giving a free water clearance of $2.1 \pm 1.48 \mathrm{ml} / \mathrm{min}$. Creatinine clearance was $77 \pm 17.7 \mathrm{ml} / \mathrm{min}$ and the sodium excretion rate $73 \pm 54.4$ 
TABLE II-Results in Patients

\begin{tabular}{|c|c|c|c|c|c|c|c|c|c|c|c|c|}
\hline $\begin{array}{l}\text { Case } \\
\text { No. }\end{array}$ & Age & Sex & $\begin{array}{c}\text { Percentage } \\
\text { Load }\end{array}$ & V & ${ }^{\mathrm{C}} \mathrm{H}_{2} \mathrm{O}_{(\mathrm{ml} / \mathrm{r}}$ & n) ${ }^{\mathrm{C} o s m}$ & $\mathrm{Na}$ & G.F.R. & $\mathrm{Po}_{2}$ & $\mathrm{PcO}_{2}$ & $\begin{array}{l}\text { Peak } \\
\text { Flow }\end{array}$ & $\begin{array}{c}\text { Previous } \\
\text { Diuretics }\end{array}$ \\
\hline $\begin{array}{r}1 \\
2 \\
3 \\
4 \\
5 \\
6 \\
7 \\
8 \\
9 \\
10 \\
11 \\
12 \\
13 \\
14 \\
15 \\
16 \\
17 \\
18 \\
19 \\
20 \\
\end{array}$ & $\begin{array}{l}64 \\
59 \\
52 \\
67 \\
61 \\
63 \\
63 \\
68 \\
56 \\
60 \\
51 \\
68 \\
64 \\
61 \\
67 \\
70 \\
75 \\
63 \\
64 \\
58 \\
\end{array}$ & 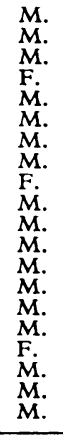 & $\begin{array}{l}93 \\
20 \\
60 \\
96 \\
47 \\
81 \\
11 \\
12 \\
20 \\
15 \\
39 \\
55 \\
97 \\
49 \\
63 \\
48 \\
56 \\
57 \\
34 \\
60 \\
\end{array}$ & $\begin{array}{l}6 \cdot 8 \\
2 \cdot 7 \\
4 \cdot 2 \\
4 \cdot 1 \\
5 \cdot 5 \\
4.5 \\
0 \cdot 6 \\
0.5 \\
1 \cdot 2 \\
0 \cdot 8 \\
2 \cdot 1 \\
4 \cdot 4 \\
5 \cdot 0 \\
5 \cdot 8 \\
4 \cdot 2 \\
8 \cdot 0 \\
3 \cdot 4 \\
4 \cdot 6 \\
1.3 \\
4 \cdot 8 \\
\end{array}$ & $\begin{array}{r}4.4 \\
0.1 \\
2.5 \\
1.9 \\
2.8 \\
3.1 \\
-0.4 \\
-7.3 \\
-0.4 \\
1.7 \\
2.3 \\
2.1 \\
2.7 \\
4.8 \\
2.0 \\
2.9 \\
2.4 \\
\end{array}$ & $\begin{array}{l}2.4 \\
2.6 \\
1.7 \\
2.2 \\
2.7 \\
1.4 \\
1.0 \\
0.9 \\
1.2 \\
0.4 \\
2.1 \\
2.9 \\
3.1 \\
3.2 \\
1.3 \\
1.7 \\
2.4 \\
\end{array}$ & $\begin{array}{c}103 \\
51 \\
67 \\
164 \\
110 \\
22 \cdot 5 \\
3 \\
2 \cdot 5 \\
24 \\
19 \\
73 \\
88 \\
145 \\
35 \\
147 \\
40 \\
34 \\
92 \\
169 \\
\end{array}$ & $\begin{array}{r}71 \\
90 \\
60 \\
75 \\
91 \\
83 \\
58 \\
49 \\
53 \\
55 \\
84 \\
82 \\
90 \\
107 \\
102 \\
95 \\
62 \\
57 \\
75 \\
95 \\
\end{array}$ & $\begin{array}{r}67 \\
57 \\
103 \\
84 \\
55 \\
61 \\
71 \\
41 \\
43 \\
70 \\
51 \\
77 \\
72 \\
44 \\
= \\
二 \\
= \\
- \\
\end{array}$ & $\begin{array}{l}41 \\
77 \\
79 \\
41 \\
55 \\
51 \\
65 \\
74 \\
74 \\
85 \\
62 \\
43 \\
45 \\
68 \\
= \\
58 \\
- \\
-\end{array}$ & $\begin{array}{r}70 \\
120 \\
65 \\
<60 \\
160 \\
65 \\
\overline{-} \\
<60 \\
\overline{-} \\
140 \\
\overline{-} \\
230 \\
140 \\
70 \\
140 \\
140 \\
-\end{array}$ & $\begin{array}{l} \pm \\
\pm \\
+ \\
\pm \\
\pm \\
+ \\
+ \\
+ \\
\pm \\
\pm \\
= \\
\pm \\
= \\
= \\
= \\
=\end{array}$ \\
\hline $\begin{array}{l}\text { Mean } \\
\pm \text { S.D. }\end{array}$ & & & $\begin{array}{l}51 \\
27 \cdot 1\end{array}$ & $\begin{array}{l}3 \cdot 7 \\
2 \cdot 11\end{array}$ & $\begin{array}{l}2 \cdot 1 \\
1 \cdot 48\end{array}$ & $\begin{array}{l}2 \cdot 0 \\
0 \cdot 83\end{array}$ & $\begin{array}{l}73 \\
54 \cdot 4\end{array}$ & $\begin{array}{l}77 \\
17 \cdot 7\end{array}$ & & & & \\
\hline
\end{tabular}

- Percentage of water load excreted in four hours.

$\mathrm{V}=$ Maximum urine flow $(\mathrm{ml} / \mathrm{min})$.

$\mathrm{Na}=$ Rate of urinary sodium excretion $(\mu \mathrm{Eq} / \mathrm{min})$

$\mu \mathrm{Eq} / \mathrm{min}$. All of these values were significantly lower than those obtained in the controls $(P<0.001)$. The serum sodium $(136 \pm$ $3.9 \mathrm{mEq} / 1)$ was also significantly reduced $(P<0.02)$.

There was a significant inverse correlation between the percentage of load passed and the arterial $\mathrm{PCO}_{2}(\mathrm{r}=-0.798$, $P<0.001$ ) (see Chart). The maximum urine flow was also inversely correlated with the $\mathrm{PCO}_{2}(\mathrm{r}=-0.759, \mathrm{P}<0.001)$. There was no significant correlation between percentage load passed and age, creatinine clearance, peak expiratory flow, or arterial $\mathrm{Po}_{2}$. The creatinine clearance was not significantly correlated with $\mathrm{PO}_{2}, \mathrm{PCO}_{2}$, or age, nor was there a significant inverse correlation between $\mathrm{Po}_{2}$ and $\mathrm{PCO}_{2}$.

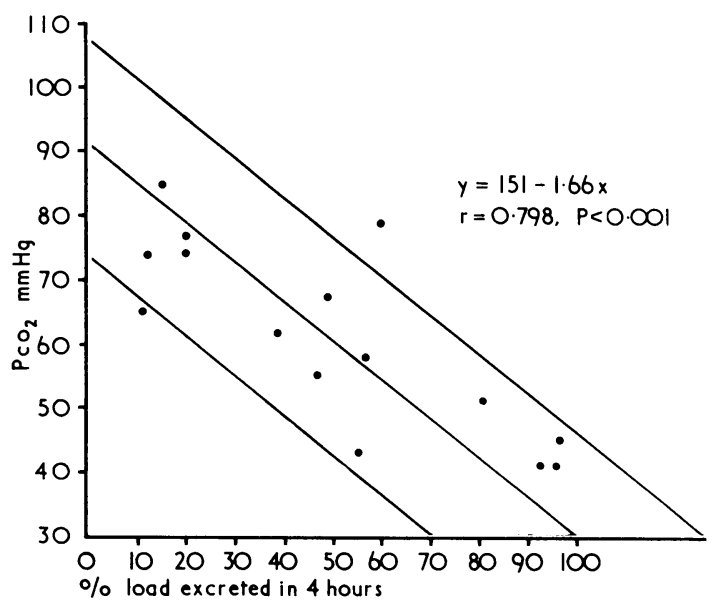

Relation between percentage of water load passed and arterial $\mathrm{PCO}_{2}$, with regression line and limits set at two standard errors of the estimate.

\section{Discussion}

There is clear evidence from this study that many patients with chronic obstructive airways disease have reduced ability to handle a water load and that the percentage of the load passed is inversely correlated with the height of the arterial $\mathrm{PCO}_{2}$. Water load given by mouth is normally absorbed from the gastrointestinal tract and results in a fall in extracellular fluid osmolarity. Stimulation of osmoreceptors leads to an inhibition of vasopressin secretion, and the water load is excreted by the kidneys. Because of the suppression of vasopressin activity the quantity of urine passed by normal subjects after a water load is mainly an index of function of the proximal nephron. Several factors may contribute to a reduced excretion of a water load. They can be summarized as incomplete absorption, reduced glomerular filtration rate, and enhanced reabsorption of water by the kidney. There is unlikely to have been impaired absorption of the water load in the patients studied. None had evidence of gastrointestinal disease, and preliminary studies with intravenous water loads have shown a similarly reduced excretion.

The glomerular filtration rate is known to be reduced in cor pulmonale (Stuart-Harris et al., 1956), and a low glomerular filtration rate and renal plasma flow may precede the onset of oedema (Platts et al., 1960). Others have confirmed the reduction in glomerular filtration rate in oedematous patients, but considered it to be insufficient to account for the excessive fluid retention (Aber et al., 1963). In this study the glomerular filtration rate was significantly lower in the patients (mean $77 \mathrm{ml} / \mathrm{min}$ ) than in the controls. Though none showed gross impairment; the lowest obtained was $49 \mathrm{ml} / \mathrm{min}$. Those with a history of oedema did not tend to have the lowest values. Had the reduced glomerular filtration rate been an important factor in the impaired response to a water load a correlation between glomerular filtration rate and percentage of load passed would have been expected. No such correlation was found. Similarly, there was no correlation between glomerular filtration rate and $\mathrm{PCO}_{2}$, though the percentage of load passed bore a close inverse correlation with $\mathrm{PCO}_{2}$. Others have also failed to show a relationship between glomerular filtration rate and blood gas tensions (Aber and Bishop, 1965).

An increase in the proximal renal tubular reabsorption of glomerular filtrate could account for the impaired sodium and water excretion and for the reduced production of free water. Such a mechanism has been shown in patients with cirrhosis and ascites (Schedl and Bartter, 1960) and is thought to occur also in congestive heart failure (Bell et al., 1964). Diureticinduced sodium depletion can cause reduced excretion of a water load by the same mechanism (Schedl and Bartter, 1960) but is unlikely to have been significant in these patients. Though several of the subjects with the smallest urine output had previously received diuretics, others on long-term diuretic therapy were among those with the most normal responses to the water load.

Though vasopressin secretion is normally suppressed under conditions of water diuresis, the possibility of overproduction or decreased inactivation should be considered. Both the reduced free water clearance and the slight hyponatraemia could result from increased vasopressin activity as well as from enhanced 
proximal tubular reabsorption of sodium and water (Bell et al., 1964). However, the reduction in osmolar clearance would not be caused by an excess of vasopressin, and is most likely to have resulted from reduced glomerular filtration rate or increased proximal reabsorption of glomerular filtrate. Because of this reduction in osmolar clearance it is felt that vasopressin is unlikely to have played a major part in the impaired excretion of water.

The association of oedema and hypercapnia in chronic chest disease is well known. The presence of oedema indicates that there is retention of both sodium and water. Experimental work with dogs has shown that chronic hypercapnia does not result in sodium retention (Schwartz et al., 1965). Experiments in man lasting up to a few hours have also failed to show sodium retention in response to hypercapnia (Longson and Mills, 1953), and a water diuresis may even be produced (Barbour et al., 1953). All of these experiments, however, were with fully oxygenated and healthy lungs, and none therefore reproduced the state of chronic hypercapnia seen in clinical practice.

The present study shows that many patients with chronic chest disease have reduced excretion of both sodium and water after a water load and that the arterial $\mathrm{CO}_{2}$ tension is closely related to the handling of water. This association does not prove a causal relationship but must raise the possibility of a direct effect of $\mathrm{CO}_{2}$.

These observations are likely to be of relevance to the oedematous state in chronic respiratory disease. It is not possible to draw definite conclusions about the exact mechanism involved and further studies are in progress to determine the importance of proximal tubular function and of vasopressin in reducing the response to a water load.

We thank Dr. Neville Oswald for his encouragement and advice, Professor J. Landon and Dr. D. G. Gibson for helpful criticism, and the anaesthetic laboratory for the blood gas determinations. We are grateful to the postal workers at the London Chief Office who acted as controls.

\section{References}

Aber, G. M., Bayley, T. J., and Bishop, J. M. (1963). Clinical Science, $25,159$.

Aber, G. M., and Bishop, J. M. (1965). Clinical Science, 28, 511.

Barbour, A., Bull, G. M., Evans, B. M., Hughes Jones, N. C., and Logothetopoulos, J (1953). Clinical Science, 12 ,

Bell, N. H., Schedl, H. P., and Bartter, F. C. (1964). American fournal of Medicine, 36, 351.

Gibson, D. G., Marshall, J. C., and Lockey, E. (1970). British Heart Fournal, 32, 399 .

Levy, M. S., Power, M. H., and Kepler, E. J. (1946). Fournal of Clinical Endocrinology, 6, 607

Longson, D., and Mills, J. N. (1953). Fournal of Physiology, 122, 81.

Platts, M. M., Hammond, J. D. S., and Stuart-Harris, C. H. (1960). Quarterly fournal of Medicine, 29, 559.

Schedl, H. P., and Bartter, F. C. (1960). Fournal of Clinical Investigation, 39, 248.

Schwartz, W. B., Brackett, N. C., jun., and Cohen, J. J. (1965). Fournal of Clinical Investigation, 44, 291.

Stuart-Harris, C. H., MacKinnon, J., Hammond, J. D. S., and Smith, W. D. (1956). Quarterly fournal of Medicine, 25, 389.

Wade, O. L., and Bishop, J. M. (1962). Cardiac Output and Regional Blood Flow. Oxford, Blackwell Scientific.

White, A. G., Rubin, G., and Leiter, L. (1953). Fournal of Clinical Investigation, 32, 931 .

\section{Cure of Lung Cancer from Incomplete Surgical Resection}

\section{R. ABBEY SMITH}

British Medical fournal, 1971, 2, 503-505

\section{Summary}

Three patients with lung cancer have been cured by incomplete removal of the cancer, which has for 20 years been the policy of this unit when complete removal is not possible. In each patient residual cancer remained on the wall of the left atrial chamber of the heart at the end of an operation for pneumonectomy.

Incomplete removal of cancer may, as a rare event, cure the patient. When residual cancer remained on any mediastinal structure other than the atrium cure has not been seen, though progress of the cancer seems to be retarded in some patients.

\section{Introduction}

Spontaneous regression of cancer has been documented (Everson and Cole, 1966). Of 176 cases of possible spontaneous regression of cancer collected by these authors, only one was in the lung (Blades and McCorkle, 1954). In an addendum a further case of regression of lung cancer was added (Bell, Jesseph, and Leighton, 1964). Sufficient detail was presented to allow the reader to reach a conclusion.

Cardiothoracic Unit, Walsgrave Hospital, Coventry

R. ABBEY SMITH, CH.M., P.R.C.s., Consultant Thoracic Surgeon
They discussed among other aspects the differences between slow progress, apparent spontaneous regression, spontaneous cure of a primary, and cure after incomplete excision or other inedequate therapy from which a cure was not to be expected. Boyd (1966) described two further cases of spontaneous regression of primary lung cancer.

In our experience neither spontaneous cure nor spontaneous regression has been observed, though delayed progress of an untreated primary and slow progression after incomplete resection are not unusual. A number of patients in both these groups have survived more than five years but have died from extension of the cancer after maximal survival of eight years. Cure as opposed to regression or delayed progress after incomplete surgery is a rarity in cancer in any site. Biopsy confirmation, a record of incomplete surgery, and necropsy confirmation of the absence of cancer throughout the body must be included among the criteria for acceptance. Fullerton and Hill (1963) described the case of a patient from whom a carcinoma of the stomach was incompletely resected in 1947. The patient died in 1963 and at necropsy no cancer was found. No other explanation than cure from incomplete surgery is possible. The extreme rarity of this event demands that claimed cases are fully reported and the data closely scrutinized.

Since 1951 incomplete resection has been considered the best available procedure if total removal of all macroscopic cancer was not possible. The early results were reported (Abbey Smith, 1957). Between 1951 and 196179 out of 450 resections were incomplete. At the conclusion of the operation on seven patients residual cancer remained on the wall of the atrium only-three have been cured by this procedure 